\title{
Multiprofessional team perception of a music therapeutic workshop developed by nurses
}

\author{
Percepção da equipe multiprofissional sobre oficina terapêutica de música desenvolvida pelo enfermeiro \\ Percepción del equipo multiprofesional sobre el taller terapéutico de música desarrollado por enfermero
}

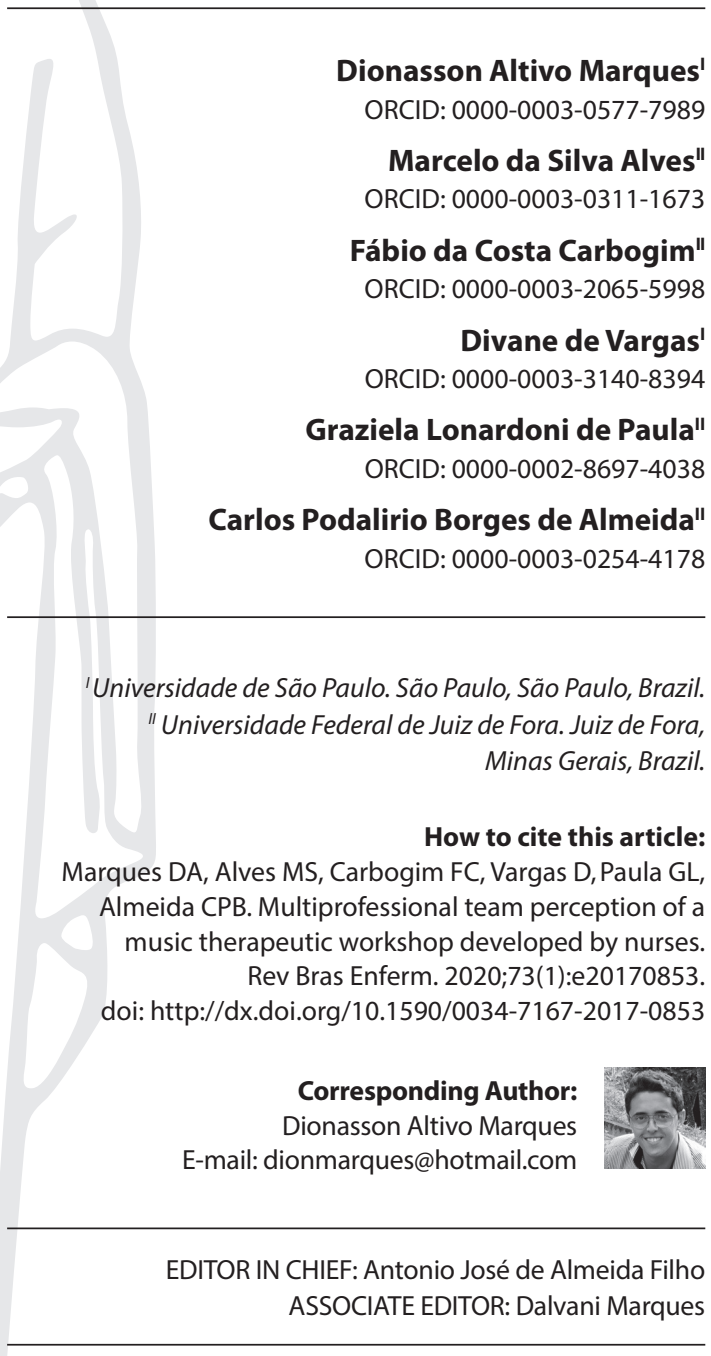

Submission: 01-05-2018

Approval: 07-05-2018

\begin{abstract}
Objective: To understand the perception of a multiprofessional team regarding the use of music in a therapeutic workshop developed by nurses. Method: Qualitative study, of the exploratory type. Data were collected through semi-structured interviews, with the participation of 13 professionals from a Psychosocial Care Center in a municipality of Minas Gerais' Zona da Mata, and analyzed according to Michel Maffesoli's comprehensive sociology approach. Results: The testimonies revealed that the use of music in the nurse's activities in mental health represents a re-signification of nursing care and favors the user's subjectivity. Final considerations: This study allowed us to show that nurses need to listen to the music that comes from the heart, from the soul, and to the truths that are not always stated in the scenarios of therapeutic practices with individuals going through psychic suffering. Therefore, the care offered should be centered on the human history, which wants to be unveiled and understood.

Descriptors: Nurses; Music; Mental Health; Mental Health Services; Nursing Care.
\end{abstract}

\section{RESUMO}

Objetivo: Compreender a percepção dos profissionais da equipe multiprofissional sobre o uso da música em oficina terapêutica desenvolvida pelo enfermeiro. Método: Estudo qualitativo, do tipo exploratório. Os dados foram coletados por meio de entrevistas semiestruturadas, com a participação de 13 profissionais de um Centro de Atenção Psicossocial em um município da Zona da Mata Mineira, e analisados seguindo-se o referencial da sociologia compreensiva, de Michel Maffesoli. Resultados: Os depoimentos revelaram que o uso da música nas atividades do enfermeiro em saúde mental representa uma ressignificação das linhas de cuidados de enfermagem e favorece a subjetividade do usuário. Considerações finais: Este estudo possibilitou evidenciar que o enfermeiro precisa ouvir a música que vem do coração, da alma e das verdades nem sempre proferidas nos cenários de práticas terapêuticas com indivíduos em sofrimento psíquico. Portanto, o cuidado ofertado deve ser centrado na história humana que convida a ser desvelada e compreendida.

Descritores: Enfermeiros; Música; Saúde Mental; Serviços de Saúde Mental; Cuidados de Enfermagem.

\section{RESUMEN}

Objetivo: Comprender la percepción de los profesionales del equipo multiprofesional sobre el uso de la música en un taller terapéutico desarrollado por enfermero. Método: Estudio cualitativo de tipo exploratorio. Los datos fueron recolectados por medio de entrevistas semiestructuradas, con la participación de 13 profesionales de un Centro de Atención Psicosocial en un municipio de la Zona de la Mata de Minas Gerais, y después analizados desde la sociología comprensiva de Michel Maffesoli. Resultados: Los testimonios demostraron que el uso de la música en las actividades del enfermero en salud mental representa una resignificación de las líneas de cuidados de enfermería y le favorece la subjetividad del usuario. Consideraciones finales: Este estudio señala que el enfermero necesita oír la música que viene del corazón, del alma y de las verdades que ni siempre se dicen en los escenarios de prácticas terapéuticas con individuos en sufrimiento psíquico. Por lo tanto, el cuidado ofrecido debe ser centrado en la historia humana que nos invita a desvelarla y comprenderla.

Descriptores: Enfermeros; Música; Salud Mental; Servicios de Salud Mental; Cuidados de Enfermería. 


\section{INTRODUCTION}

For many years, the treatment of the "mentally ill" in Brazil was directly related with prolonged hospitalization in psychiatric hospitals and withdrawal from social and family relationships. With the idealism from the Psychiatric Reform process, political discussions began among health professionals, aiming at transforming care practices in the field of mental health by gradually replacing the asylum model $\mathrm{I}^{(1-2)}$.

As a result of these debates, it is essential to articulate diverse actions so that the Psychosocial Care model may be consolidated. To that end, substitutive services have increased throughout the national territory due to the provision of care for individuals undergoing psychic suffering in accordance with the guidelines established in the context of the reform ${ }^{(3-4)}$.

In this sense, the creation of Psychosocial Care Centers (CAPS) stand out, aiming to contribute to the psychosocial rehabilitation of its users, as delimited by Ordinance 336, of February 19, 2002. It is a service of communitarian character, committed with providing care to individuals with mental disorders, severe, moderated, or light. Among the modalities of CAPS, CAPS III is an outpatient service that operates daily in municipalities with a population of more than 200 thousand inhabitants, in a 24 -hour period ${ }^{(5)}$.

Among the assistance resources developed in these spaces, the therapeutic workshops stand out, which are socialization group activities coordinated by professionals from the CAPS multiprofessional team, assistants, interns, or researchers ${ }^{(6)}$. In nursing, interest in music as a psychosocial therapy resource has gained prominence in the care aimed at the minimization of painful processes, as an instrument to facilitate the interpersonal relationship between the client and the nurse, to reduce stress factors and form bonds ${ }^{(7)}$.

Supporting these beneficial effects, an American study presented evidence that music does not pose any threats, but offers coping mechanisms for exploring our problems, helping to identify skills and abilities, stimulating creativity, and providing a therapy based on individual potentialities. Therefore, many are the dimensions stimulated by this therapeutic resource that affects not only the mind, but also people's body and soul ${ }^{(8)}$.

Based on the findings, despite the scientific evidences highlighted by national and international studies ${ }^{(7-9)}$ on the benefits and broad significance of music regarding positive behavioral changes in humans, after reviewing the collections of the Virtual Health Library (VHL), using the Descriptors in Health Sciences (DeCS) "Nurses" and "Music" and "Mental Health", we did not find any published studies on this topic. When mentioned on the United States National Library of Medicine (PubMed), by the descriptors "Nurses" and "Music" and "Mental Health", we verified the inexistence of studies dealing with the perspective of mental health professionals regarding the action of nurses in therapeutic workshops in which music was used as a care strategy for individuals with psychic suffering.

Thus, this study is justified by the scarcity of research with this thematic approach and by the need to assign a new meaning to nursing care in the context of mental health considering the conceptions of the multiprofessional team acting in one of the substitutive services to psychiatric hospitals. The following research question motivated this investigation:"How can nurses contribute to the re-signification of their mental health care by carrying out music therapeutic workshops in the perception of the multiprofessional team?"

\section{OBJECTIVE}

To understand the perception of a multiprofessional team regarding the use of music in a therapeutic workshop developed by nurses.

\section{METHOD}

\section{Ethical aspects}

The research began after the approval of the Research with Human Beings Ethics Committee of the Federal University of Juiz de Fora, in accordance with Resolution 466, of December 12,2012 , and its complementary guidelines.

\section{Theoretical-methodological reference}

This study is based on the comprehensive sociology approach proposed by the sociologist Michel Maffesoli. Methodologically, his analyses are based on phenomenology to support its concepts and propositions. This fact contributes for his ideas to be typified by a phenomenological and comprehensive sociology ${ }^{(10)}$.

The comprehensive sociology established five theoretical and sensitivity assumptions, named: 1) criticism of schematic dualism; 2)"form"; 3) relativistic sensibility; 4) stylist research; and 5) libertarian thought. However, this methodological reference alludes to complicity, which can be explained as the attitude of empathy and allows the involvement between the researcher and the object to be studied. Thus, to develop research and obtain results that are linked to the social context, it is necessary to carefully introduce subjectivity in the analysis process ${ }^{(11)}$.

\section{Type of study}

This is a qualitative study of the exploratory type, due to its adequacy to the understanding of social phenomena. Qualitative research has the specific characteristics of apprehending questions, making it possible to answer to the foundations of the object of study. Its approach has broad meanings that allow us to glimpse perceptions, perspectives, narratives, ideologies, and behaviors, which cannot be reduced to variables, as well as their intrinsic execution modes ${ }^{(12)}$. This research was carried out and structured based on the the Consolidation Criteria for Reporting Qualitative Research (COREQ) $)^{(13)}$.

\section{Methodological procedures}

\section{Study scenario}

This study was carried out in a CAPS III of a municipality of Zona da Mata, state of Minas Gerais, Brazil. The main researcher voluntarily assumed the coordination of the music therapeutic workshop at the CAPS before the beginning of this study, remaining as coordinator until the period of development of this research (between February 2, 2015 and May 18, 2016), to "be alongside" the users and thus be able to, through the musical 
actions, create a space of socialization, care, and production of subjectivities, in addition to developing this research.

The meetings happened weekly and lasted for an hour. In the music therapeutic workshop, in addition to the musical proposal developed and idealized with the effective participation of users, health education practices were carried out by the workshop coordinator, with the purpose of promoting and preventing vocal health. These actions were planned and structured according to the request, curiosity, and thematic interest of the users who participated.

The themes were chosen by the users and were related to the activities they performed in the music workshop. Among the themes addressed, the following stood out: the harmful effects of tobacco use and impairments in the speech apparatus; hoarseness; increased water intake; changes in eating habits; and the need to stretch for instrumentalists and vocalists. It is worth mentioning that all the reflexive problematization was developed with the purpose of favoring the exchange of knowledge and experiences between the researcher and the users from their needs.

The entire program of the music workshop was established according to the participants' desires and interests. In all meetings, the users organized themselves in a circle for the introductory activities of corporal relaxation and vocal warm-up. Thus, the actions were coordinated and developed allowing a space of subjectivity and socialization.

The musical instruments used in the workshop were: guitar, electric guitar, drums, keyboard, tambourine, and pandeirola, all owned by the institution. It should be added that these instruments were played by the users who had mastery of musical techniques and theories, even before the disorder was established, who played and sang songs chosen by them as a way to rescue autonomy and social emancipation.

As a result of these therapeutic activities, a backing vocal music group was created, composed by ten users who participated assiduously in the music therapeutic workshop, with seven vocalists and three instrumentalists.

\section{Data source}

A total of 13 professionals who were part of the CAPS multiprofessional team participated in the study, including two social workers, four psychologists, four nurses, and three nursing technicians, selected using the inclusion criteria: professional experience of at least one year; attending at least three meetings of the workshop, to witness the daily activities carried out; and expressing acquiescence by signing the informed consent form.

The selection of participants was carried out by the convenience sample technique. The exclusion criteria were: professionals who were on vacation time during data collection and those who declared to be unavailable to participate and witness the activities carried out in the music workshop.

\section{Data collection and organization}

The data collection process happened between June 11 and September 13, 2015. The instrument of data collection was a semistructured script, and the questions that guided the interview were: (i) What do you think of the music therapeutic workshop?; (ii) How do you perceive the behavior of CAPS users in the music therapeutic workshop?; (iii) What meanings or senses would you attribute to the performance of nurses in the music therapeutic workshop? The data from the interviews were manually treated and transcribed in the Microsoft Word 2016 software.

Each participant was invited to join this research and the researcher informed them about the study's goal, the expected benefits, and the destination of all the testimonies provided. The testimonies collected were recorded, with the permission of each respondent, by a digital recorder. All interviews were carried out in the CAPS, without interference, and lasted approximately from 30 to 50 minutes.

The identity of the professionals was preserved by the use of the nomenclature of the seven musical notes, with the addition of notes that represent a semitone above the successive conventional notes, due to the number of respondents being equal to thirteen. Therefore, the participants' statements were identified as follows: C, D, E, F, G, A, B, C\#, D\#, E\#, F\#, G\#, and A\#. "\#" means sharp, following the musical notation. They were thus names, following this sequence, according to the chronological order in which the interviews took place.

\section{Data analysis}

Initially, for the comprehensive analysis of the speeches, a careful reading of all the transcribed testimonies was performed, assuming a interrogative relation, to identify the meaning attributed by the participants. From this reading, the meanings were analyzed and grouped, according to the nucleus of meaning of words that express an idea of equivalent meaning, thus forming the categories of analysis ${ }^{(12)}$.

After the process of analysis of the interviews, it was possible to list two categories, named from songs fragments: "Oh, if the whole world could hear it/ I have so much to tell, to say that I learned [...]"; "[...] We have hopes for the world and the world has hopes for us [...]". These are translated from the original songs in Portuguese, respectively: "Azul da cor do mar" by Tim Maia and "Paciência” by Lenine.

The analytical device consisted of two stages: the first represents the contemplation of the inside, the perception of the occult, called "intuition". In the intuitionist perspective, it is possible to obtain an intimate understanding related to daily experiences. Therefore, the researchers need to see what is hidden, as they observe what is perceptible, since, to reach depth, it is first necessary to examine the surface ${ }^{(14)}$.

The second stage, named "metaphor", expresses the analysis process that allows the researcher to apprehend the investigated phenomenon without having the pretension to explain it. To metaphorize is to reveal the senses appropriating comparisons, approximations, similarities, and figurative examples. However, it is essential to harmonize the content of the interviews by bringing it closer to the investigated phenomenon ${ }^{(14)}$.

\section{RESULTS}

\section{"Oh, if the whole world could hear it/ I have so much to tell, to say that I learned [...]"}

The use of music and its meanings in the daily care of CAPS were expressed by the participants as a possibility for nursing 
care, through the integration of musical resources in the attenuation of psychic suffering.

These findings, perceived in the testimonies, characterize the meaning of music, indicating the manifestations that emerge in the users who participate in the workshop, being evidenced in the following excerpts:

[...] Music begins to have a completely therapeutic meaning in the place this individual assigns for himself. They say: "I'm a member of the band"; "I play on the music workshop"; "I play the drums"; "I play the pandeirola"; "I sing". Thus, it's a moment of much expression, of integration, of self-esteem and autonomy for the users. (D)

Music makes the users feel good. Music is happiness; is noise; is sound; I believe that [...]. Through music, they learn to listen, sing, communicate with one another. This is also helpful! (F)

[...] When things get too tense or in moments of anguish, there is always an user who says: "let's put some music into this conversation!". Music brings something suiting to the environment, it summons participation and movements [...]. Music has a very important social appreciation [...]. (A)

Due to the instinct of protection and care for themselves, human beings appropriate strategies that provide comfortable experiences for their well-being, as evidenced in the testimony:

I notice that some users pick songs that make them remember past situations [...]. I notice that many of the songs they pick in the workshop have sad lyrics and melodies, but they do not evoke negative emotions to these individuals. They focus on the beauty of the song and acquire pleasant experiences that make them feel good, regardless of the rhythm. (C\#)

When mentioning the manifestations and influences of music, professionals emphasized that the use of this medium is an important resource in the treatment of individuals with psychic suffering, as it enables relaxation, psychic organization, and joy. These ideas can be identified in these statements:

Music reduces stress, promotes mind relaxation, takes the individual away from submission conditions of life, of being an object to another, and makes them assume the leading role of their own existence. (F\#)

Through music, it is possible to organize the individual, making him realize his potential through his voice, a voice that has always been silenced by society through social exclusion. Music converts sadness into happiness, reduces stress levels, anyway, music helps with socialization, pacifies, it is an important treatment instrument, right? (D\#)

This same thought can be perceived in the respondents' answers when questioned about their conceptions regarding the meaning of music as a care strategy in therapeutic workshops developed by nurses:

One of the important meanings of music in nursing care refers to the creativity of the individual; music, when it touches the emotion, makes the individual more creative. It offers support to face the adversities and sadness of daily life [...]. (A\#)
I'm sure that music is a therapy and it acts on the disorder of each individual. I see that the nurse's work reaches the body and positively affects the inside. Not to mention that where there is music, there is creativity, spontaneity. It is wonderful to see people with a certain cognitive compromise playing the music notes, it is contagious! (C)

\section{“[...] We have hopes for the world and the world has hopes for us $[. . .]^{\prime \prime}$}

The respondents' conceptions presented in this category show a professional understanding of the nurses' performance in the music therapeutic workshop. It is worth mentioning that the music was conducted by a professional nurse and chosen along with the users who participated as a proposal for mental health care and research.

This discussion elucidates the development of nursing care to meet the users' perspectives, as described in the testimonies:

What draws more attention in nursing is exactly this, this more humane care with which professionals treat users [...]. At the music workshop, I see this point of the nurse calling, inviting the users and trying to integrate them to the workshop in a humane way [...]. (E)

I see the work of the nurses has been innovative, a true work of solidarity [...]. Nursing is health and has been working in a more playful way [...]. (D)

Based on the following statements, we noticed that the daily activities of nurses in the CAPS need to be re-signified, with a care approach that favors the subjectivity of the service users. This refers to the use of innovative resources that correspond to the recommendations of the Psychiatric Reform movement:

I think that nurses need to be increasingly committed, participative, and involved in care through therapeutic workshops. It is important that these professional employ new therapeutic resources based on the construction of the individuals' subjectivity, such as music, for example [...]. (C\#)

[...] Nurses need to be open to other forms of care, disentangling themselves from conventional practices and working on the subjectivity [...]. (F)

The professionals also reported the importance of the implementation of new care resources and the need for contact to achieve effective nursing care in the CAPS, as can be seen in the following statements:

The goal of this workshop is precisely to care using music in a humane way. The nurse participates in this process, and this is very important! Nursing uses the touch, however, in this context it is not a physical touch, but rather a $n$ inner touch through the art of music and contact with the user. This deconstructs the image that we have of nurses with trays [...]. (E\#)

It is necessary for the nurse to know how to conduct these new modalities of therapeutic resources with the use of music because there is no secret, no technique, it is a question of tact. Theory is important, but what makes a difference is the availability, the 
contact with the other, it is to want to innovate with care, forsaking the restrictions of conventional practices [...]. (G)

\section{DISCUSSION}

The results of this study, referring to the first category of analysis, reveal the understanding of the senses of music as a mental health care and its possible contributions regarding the behavioral aspects of the users who participated in the music therapeutic workshop. The knowledge described point to the understanding that musical activities are capable of favoring the expression of feelings.

In confirming what has been described in the literature ${ }^{(15)}$, we identified that, by going through the broad meaning of music, it can be defined that this artistic resource can be produced by users of the health service and by professionals who exercise the therapeutic relationship. Playing musical instruments and singing is characterized as an important stimulus due to the musical interaction. Thus, the meanings of approaches with music will diversify according to the diagnosis and the priority needs of each individual.

To illustrate these concepts, it is pertinent to act in a balanced way according to the melody emanating from the other. However, making music along with the other represents, metaphorically, a truth with abstract meanings ${ }^{(16)}$. This represents the insertion of the playful, the dreamlike, which involves society, and of the imaginary as parameters of social life that allow for collective reflections and make us realize that there is an existential reason in everything ${ }^{(17)}$.

In the context of this discussion, we found that musical interventions, mediated by the interaction between professionals and users, are capable of eliciting positive behaviors that allow the regulation, management, and transformation of the individuals' emotions, minimizing the episodes of lethargy, affective blunting, and stress ${ }^{(18-19)}$.

When confirming these conceptions, a study carried out with the use of psychological tests and magnetic resonance imaging in the brain, specifically in the region of the prefrontal cortex in a given population, after musical interventions, proved that the contact with musical activities modifies behavior and neural responses, aids in mood stabilization, and interferes with individual differences, such as emotions, levels of anxiety, depression, and neuroses ${ }^{(9)}$.

In this sense, we highlight the importance of sharing affectivity, emotions, expectations, and other sensations inherent to the individuals that allow us to affirm that social life is made of restlessness and a sensible realism. Based on this outline, music in its various aspects portrays an expression of popular joy, even amid moments of sadness and discontent ${ }^{(17)}$.

Consistent with a previous study ${ }^{(19)}$, sadness is often associated with some feelings of pleasure along the human existential trajectory. Therefore, music composed by a melancholic harmonization can often be interpreted as a pleasant stimulus, capable of inducing a favorable affective state that helps the development of effective therapies for disorders such as depression, in which the ability to feel pleasure is attenuated.

It was observed that one of the meanings and senses of music demonstrates that mentally fatigued individuals, when coming into contact with music and its expressions, experience a reduction of their mental exhaustion and of the psychomotor deterioration, both at the behavioral and cognitive levels ${ }^{(20)}$.

Corresponding to this perspective, through the phenomena manifested in the daily lives of those who receive care, a vital desire is constantly revealed. This impulse invigorates inert societies and leads them to states of plenitude and social well-being, making individuals enjoy freedom and sensitiveness and also allowing them to identify their real conflicts, assuming attitudes that offer them resolutiveness ${ }^{(16)}$.

In the second category of analysis, the participants expressed their considerations through the use of music in the mental health care provided by the nurse. However, the possible influence of the playful in nursing actions can be denoted by metaphorical thinking, in which, taking the sounds, colorations and what is exhaled into consideration, the configurations are allocated in such a way to benefit pleasures and feelings in a collective way ${ }^{(11)}$.

In this perspective, the Psychosocial Care Network (RAPS), indicated by Ordinance no. 3,088, from December 23, 2011, satisfactorily includes the work of nurses and their lines of care in the field of mental health, highlighting their importance in Psychosocial Attention. To this end, the nursing care practice must follow the transformations caused by the Psychiatric Reform to legitimize the actions of the nurse in this care model ${ }^{(3)}$.

Therefore, it is believed that, with the reformulations in the context of mental health, nurses need to reflect on their praxis with the intention of adapting it to the propositions of substitutive services. Thus, their actions need to be based on creativity, flexibility, and teamwork, with a view to disarticulate the asylum $\operatorname{archetype}^{(21)}$.

In this sense, studies ${ }^{(19,22-23)}$ show that understanding and empathy become essential in the performance of nurses, as they favors the process of forming bonds, facilitating the emotional care provided to the users of the service. Thus, the use of music as nursing care facilitates the development of skills and new forms of relationship with the other, contributes to the improvement of the communication process, and moves away from behaviors that favor affective blunting and social isolation.

However, the society in which the body is exalted, loved, and valued is called somatophilic. These evidences represent a phenomenon that circumstantially affects social life. All these aspects are related to Postmodernity and permeate the nursing practice in its multiple dimensions: educational, of care, administrative, and artistic, proving that the biomedical model has a strong prevalence over the subjectivity of the individual with psychic suffering ${ }^{(17)}$

\section{Study limitations}

This study is innovative in its conception, however, it works with the perception of a multiprofessional team of a CAPS, not including other teams of different mental health services and the understanding of the users of the workshop, which would be desirable and could contribute to the understanding of this phenomenon on the part of those who receive and give, respectively, this care technology. Therefore, we suggest that new studies are carried out, addressing such perspectives on 
integration and involvement of these individuals in a music therapeutic workshop in the CAPS.

\section{Contributions for the areas of nursing, health, or public policies}

The results of this study provide contextual information that enables us to think about new technologies of mental health nursing care within the scope of services in the model of Psychosocial Care and subsidize discussions that contribute to a greater visibility to the professionals working in this assistance context, specifically nurses, since the discourses were constituted from the perspective of those who experience psychic suffering daily.

It should be emphasized that this study points out to a relevant care technology, which suggests new proposals for therapeutic actions of nurses in mental health, and collaborates directly for professional autonomy, work control, active inclusion of this professional in the technical teams of the new apparatus of RAPS and, finally, reinforces, with scientific arguments, attitudes that can contribute to the resignification of nursing care approaches.

\section{FINAL CONSIDERATIONS}

From the presented results, we infer that music represented as an art of expression of feelings through sounds finds materiality in nursing. It becomes an important existential, inter-human and, above all, dialectic experience, strengthening the idea that individuals in psychic suffering must assume a leading role.

The participants through their experiences and conceptions produced meanings in their discourses on the re-signification of the care provided by nurses that suggest that these professionals should be daring, create an opportunity of a horizontal view towards the shared existence, felt and sensitized towards the differences that separate beings who care from those who are cared for.

However, nurse professionals must listen to the music that comes from the heart and soul and the truths that are not always uttered in the scenarios of therapeutic practices with individuals in psychic suffering, demystifying their performance as merely a conventional technical procedure and practice. Therefore, the care offered should be centered on the human history, which wants to be unveiled and understood.

\section{REFERENCES}

1. Waidman MAP, Marcon SS, Pandini A, Bessa JB, Paiano M. Assistência de enfermagem as pessoas com transtornos mentais e as famílias na Atenção Básica. Acta Paul Enferm. 2012;25(3):346-51. doi: 10.1590/S0103-21002012000300005

2. Olschowsky A, Wetzel C, Fernando JS, Pinho LB, Camatta MW. Evaluation of intersectoral partnerships for mental healthcare in the Brazilian family health strategy. Texto Contexto Enferm. 2014;23(3):591-9. doi: 10.1590/0104-07072014001970012

3. Esperidiao E, Silva NS, Caixeta CC, Rodrigues J. The Psychiatric Nursing, ABEn and the Scientific Department of Psychiatric and Mental Health Nursing: progress and challenges. Rev Bras Enferm. 2013;66(spe):171-6. doi: 10.1590/S0034-71672013000700022

4. Lapischies SRC, Jardim VMR, Kantorski LP. Fatores associados à satisfação no trabalho em Centros de Atenção Psicossocial. Rev Latino-Am Enfermagem. 2014;22(6):950-8. doi: 10.1590/0104-1169.3474.2500

5. Ministério da Saúde (BR). Portaria n 336, de 19 de fevereiro de 2002. Dispõe sobre a possibilidade de importadores e fabricantes de instrumentos de medição de obterem autorização para emitir declaração de conformidade em substituição à verificação inicial [Internet]. Brasília: Ministério da Saúde; 2002 [cited 2017 Sep 15]. Available from: http://bvsms.saude.gov.br/bvs/saudelegis/gm/2002/ prt0336_19_02_2002.html

6. Ministério da Saúde (BR). Secretaria de Atenção à Saúde. Departamento de Atenção Básica. Departamento de Ações Programáticas Estratégicas. Saúde mental [Internet] (Cadernos de Atenção Básica, n 34). Brasília: Ministério da Saúde; 2013 [cited 2017 Oct 18]. Available from: http://189.28.128.100/dab/docs/portaldab/publicacoes/caderno_34.pdf

7. Taets GGC, Barcellos LRM. Música no cotidiano de cuidar: um recurso terapêutico para enfermagem. Rev Pesq Cuid Fundam Online. 2010;2(3):1009-16. doi: 10.9789/2175-5361.2010.v2i3.\%25p

8. Chwalek CM, McKinney CH. The Use of Dialectical Behavior Therapy (DBT) in music therapy: a sequential explanatory study. J Music Ther. 2015;52(2):282-318. doi: 10.1093/jmt/thv002

9. Carlson E, Saarikallio S, Toiviainen P, Bogert B, Kliuchko M, Brattico E. Maladaptive and adaptive emotion regulation through music: a behavioral and neuroimaging study of males and females. Front Hum Neurosci. 2015;9:466. doi: 10.3389/fnhum.2015.00466

10. Barros EP. A totalidade cósmica em Maffesoli: Affaire Tremblay e franco-maçonaria. Intexto [Internet]. 2015[cited 2017 Oct 27];(32):212-8. Available from: http://seer.ufrgs.br/index.php/intexto/article/view/55720/34009

11. Maffesoli M. O conhecimento comum: introdução a sociologia compreensiva. Porto Alegre: Sulina; 2010.

12. Minayo MCS. O desafio do conhecimento: pesquisa qualitativa em saúde. 14a ed. São Paulo: Hucitec; 2014.

13. Tong A, Sainsbury P, Craig J. Consolidated criteria for reporting qualitative research (COREQ): a 32-item checklist for interviews and focus groups. Int J Qual Health Care. 2007;19(6):349-57. doi: 10.1093/intqhc/mzm042

14. Maffesoli M. Elogio da razão sensível. 4ª ed. Petrópolis: Vozes; 2008.

15. Carr C, Odell-Miller H, Priebe S. A systematic review of music therapy practice and Outcomes with acute adult psychiatric in-patients. PLoS One. 2013;8(8):e70252. doi: 10.1371/journal.pone.0070252

16. Maffesoli M. O tempo retorna: formas elementares da pós-modernidade. Rio de Janeiro: Forense Universitário; 2012. 
17. Maffesoli M. A república dos bons sentimentos. São Paulo: Iluminuras; 2009.

18. Moore KS, Hanson-Abromeit D. Theory-guided therapeutic function of music to facilitate emotion regulation development in preschoolaged children. Front Hum Neurosci. 2015;9:572. doi: 10.3389/fnhum.2015.00572

19. Sachs ME, Damasio A, Habibi A. The pleasures of sad music: a systematic review. Front Hum Neurosci. 2015;9:404. doi: 10.3389/ fnhum.2015.00404

20. Guo W, Ren J, Wang B, Zhu Q. Effects of relaxing music on mental fatigue induced by a continuous performance task: behavioral and ERPs evidence. PLoS One. 2015;10(8):e0136446. doi: 10.1371/journal.pone.0136446

21. Cavalcanti PCS, Oliveira RMP, Caccavo PV, Porto IS. O cuidado de enfermagem nos Centros de Atenção Psicossocial. Ciênc Cuid Saúde. 2014;13(1):111-9. doi: 10.4025/cienccuidsaude.v13i1.19458

22. Oates J, Drey N, Jones J. 'Your experiences were your tools'. How personal experience of mental health problems informs mental health nursing practice. J Psychiatr Ment Health Nurs. 2017;24(7):471-9. doi: 10.1111/jpm.12376

23. Franzoi MAH, Santos JLG, Backes VMS, Ramos FRS. Musical intervention as a nursing care strategy for children with autism spectrum disorder at a psychosocial care center. Texto Contexto Enferm. 2016;25(1):e1020015. doi: 10.1590/0104-070720160001020015 